\title{
Nesting biology of four species of Trypoxylon (Trypargilum) (Hymenoptera: Crabronidae) in Chaco Serrano woodland, Central Argentina
}

\author{
Mariana L. Musicante \& Adriana Salvo
}

Centro de Investigaciones Entomológicas de Córdoba-Instituto Multidisciplinario de Biología Vegetal, F.C.E.F. y N. Universidad Nacional de Córdoba, Av. Vélez Sarsfield 1611-(X5016GCA)-Córdoba, Argentina;

marymusicante@yahoo.com.ar, asalvo@com.uncor.edu

Received 25-VIII-2009. Corrected 30-IV-2010. Accepted 31-V-2010.

\begin{abstract}
Trypoxylon (Trypargilum) (Crabronidae) wasps are solitary spider predators that can build their nests in artificial trap-nests, which enables study of their nesting architecture and biology. Twenty traps (each containing 15-30 internodes of cane) were placed in each of nine sites of Chaco Serrano Woodland in Central Argentina (Córdoba) in October 2005, and were recovered in June 2006. We obtained 91 nests of four species of Trypoxylon (Trypargilum). In the laboratory, each Trypoxylon nest was sectioned longitudinally to study its architecture. The number of brood cells was counted, and the occurrence and length of vestibular and intercalary cells and the pre-closing plug space were recorded. We measured the diameter of the cane entrance, total length of the nest, length of each brood cell, maximum thickness of mud partitions and closing plug thickness. We also recorded the cell contents: the wasps, their natural enemies and the prey spiders. Mortality was assessed and the sex ratio calculated for each species. Finally, the nests were examined to help clarify the function of the vestibular cell. The nest architecture was similar in the four species, with linear brood cells located one after the other separated by mud partitions, as in other species of the subgenus Trypargilum. Forty-eight percent of the nests had vestibular cells, but only two had intercalary cells. The thickness of the mud partitions and the length of the brood cells differed among species and were related to the size of the emerged wasp. The diameter of the nest entrance was directly related to the average length of the fore-tibia. Sex ratios of all species did not deviate from 0.5. Mortality due to parasitoids (Eulophidae; Melittobia sp.) was similar among species, while the mortality due to cuckoo wasps (Chrysididae) in T. lactitarse was higher than in the other species. The presence of vestibular cells was not related either to the mortality due to natural enemies or to the orientation of the trap in the field. Spiders in the family Araneidae were the most frequently collected prey. Rev. Biol. Trop. 58 (4): 1177-1188. Epub 2010 December 01.
\end{abstract}

Key words: vestibular cell, sex ratio, natural enemies, prey spider, nest architecture, trap-nests, Chrysididae, Eulophidae.

Crabronidae wasps are cosmopolitan solitary predators which use insects and spiders as provisions for their nests. Their nesting habits vary within the family: from nests dug into the soil or built in pre-existing cavities, to free nests made of mud or vegetable materials attached to different substrates (Bohart \& Menke 1976, Menke \& Fernández 1996). The genus Trypoxylon Latreille, 1796 includes 660 species worldwide (Hanson \& Menke 1995), with the highest number occurring in the Western hemisphere, particularly in South and Central America. The species of the subgenus Trypargilum Richards, 1934 are restricted to the New World (Bohart \& Menke 1976, Coville 1982). Some species of this subgenus constructs mud nests; others utilize pre-existing tubular cavities that are divided into a linear series of cells by mud partitions. Females provide each cell with several paralyzed spiders, and then lays 
an egg on one of the last prey stored (Coville 1982). Meanwhile, a male usually guards the nest, chasing away ants, parasitic flies and cuckoo wasps, and defending the nest against conspecific males (Brockmann \& Grafen 1989, Brockmann 1992).

The cavity adopted by the wasp may be a tube in the hollowed pith of a twig, an old insect borehole in rotten wood, or many other kinds of holes. This opportunistic nesting habit allows researchers to use trap-nests in order to study many aspects of the biology of these wasps (Krombein 1967). In a pre-existing tubular cavity, the female constructs a linear series of cells, with bi-concave, smooth mud partitions between them. Some nests have an empty space at or near the outer end of the boring, called a "vestibular cell" (VC), and may also have a variable number of so-called "empty intercalary cells", which are non-provisioned cells between two store cells (Krombein 1967), but their function is still unclear (Asís et al. 2007). To finish the nest, the female builds a closing plug, with a smooth, concave inner surface and a rough, flat outer surface. The dimensions and the number of nest elements vary among Trypoxylon species (Krombein 1967, Genaro 1996), and nests also differ in the quantity and proportion of prey spiders stored (Krombein 1967, Camillo et al. 1993, Camillo et al. 1994, Jiménez \& Tejas 1994).

Although many studies of the biology of Trypoxylon (Trypargilum) have been performed using trap-nests in Brazil (Camillo et al. 1993, Camillo et al. 1994, Morato \& Campos 1994, Assis \& Camillo 1997, Camillo \& Brescovit 1999a, b, 2000, Buschini \& Wolff 2006, Buschini et al. 2006, Buschini et al. 2008), Costa Rica (Coville \& Coville 1980, Coville 1981, Coville et al. 2000) and Cuba (Genaro et al. 1989, Genaro 1996), there are no reports on this genus in Argentina. The aim of this study was to present comparative information about the nesting biology of four species of Trypoxylon (Trypargilum), using trap-nests in Chaco Serrano woodland in Córdoba, Argentina and to analyze Trypoxylon nests to help clarify the function of the outermost empty chamber of the nest, the vestibular cell (VC).

\section{MATERIALS AND METHODS}

Study area: The study area was in central Argentina $\left(31^{\circ} 10^{\prime} \mathrm{S}\right.$ to $31^{\circ} 30^{\prime} \mathrm{S}$ and $64^{\circ} 00^{\prime} \mathrm{W}$ to $64^{\circ} 30^{\prime} \mathrm{W}$ ) with an elevation of about $700 \mathrm{~m}$. Annual rainfall is $750 \mathrm{~mm}$ concentrated mostly in the warm season (October-April), with a mean maximum temperature of $26^{\circ} \mathrm{C}$ and minimum of $10^{\circ} \mathrm{C}$ (Luti et al. 1979). The area was originally covered by Chaco Serrano vegetation of low and open woodland (Luti et al. 1979), with an open tree stratum up to $15 \mathrm{~m}$ high, 1 to $3 \mathrm{~m}$ high shrubs covering $10-80 \%$ of the ground, a herbaceous layer (up to $95 \%$ cover), and many vines and epiphytes (Cabido et al. 1991). Native vegetation is currently restricted to isolated patches within an intensely managed agricultural matrix (Zak et al. 2004).

Nine forest fragments, ranging from 0.4 ha to more than 15000 ha, embedded in an agricultural matrix largely dominated by wheat in winter and soy or maize in summer, were chosen as sample sites (Site 1: 0.57ha, 31 ${ }^{\circ} 12^{\prime} 53.1^{\prime \prime}$ " S-64 $15^{\prime} 36.2^{\prime \prime} \mathrm{W}$; site 2 : $1.14 \mathrm{ha}, 31^{\circ} 11^{\prime} 44.4^{\prime \prime}$

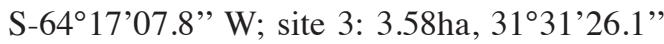
S-64²7'30.9' W; site 4: $10.07 \mathrm{ha}, 31^{\circ} 12^{\prime}$ '59.7' S-64'15'15.1" W; site 5: $13.77 \mathrm{ha}, 31^{\circ} 34^{\prime} 54.8^{\prime \prime}$ S-64'26'29.9" W; site 6: $29.53 \mathrm{ha}, 31^{\circ} 17^{\prime} 4.8^{\prime \prime}$ " S-6414'0" W; site 7: + 1 000ha, 31 ${ }^{\circ} 09^{\prime} 12.0^{\prime \prime}$ S-64²0'31.8" W; site 8: +1 000ha, 31 ${ }^{\circ} 11^{\prime} 01.8$ " S-64'15'29.7' W; site $9+1000$ ha, 31 $27^{\circ}$ '12.4" S- 64²5'17.3”'W) (Fig. 1).

Trap-nests: The Trypoxylon species nests were obtained using traps made of plastic tubes $(15 \mathrm{~cm}$ in diameter and $20 \mathrm{~cm}$ long), each containing 15-30 internodes of Phyllostachys aurea Carr. Ex A. \& C. Rivière (Poaceae) (Fig. 2). A range of cane diameters from 0.2 to $2 \mathrm{~cm}$ were used (Tscharntke et al. 1998).

Twenty traps per site were placed on trees, 1 to $1.5 \mathrm{~m}$ above ground, each trap separated from the others by at least $10 \mathrm{~m}$. The traps were set up in the field in spring (October 2005) and recovered in autumn (June 2006). In the 


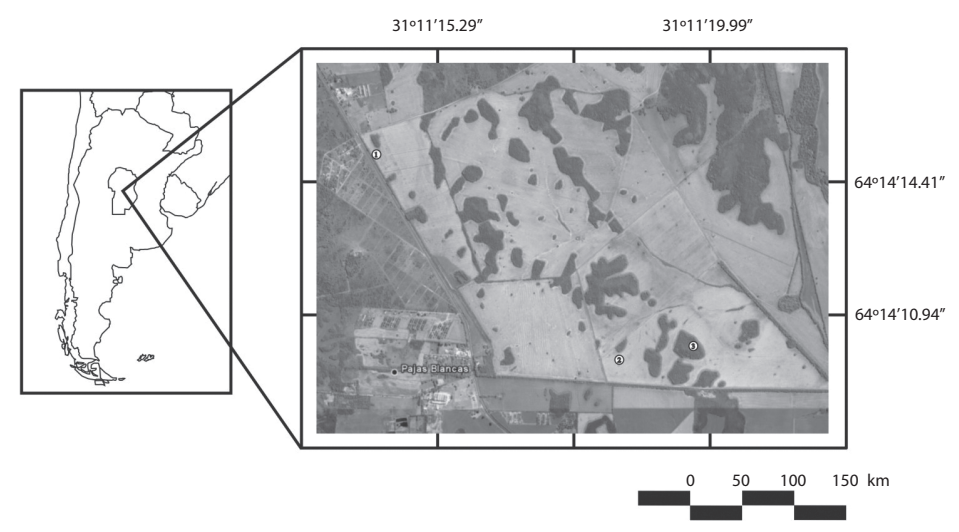

Fig. 1. Study area and satellite image showing three forest fragments of the nine Chaco Serrano sites studied.

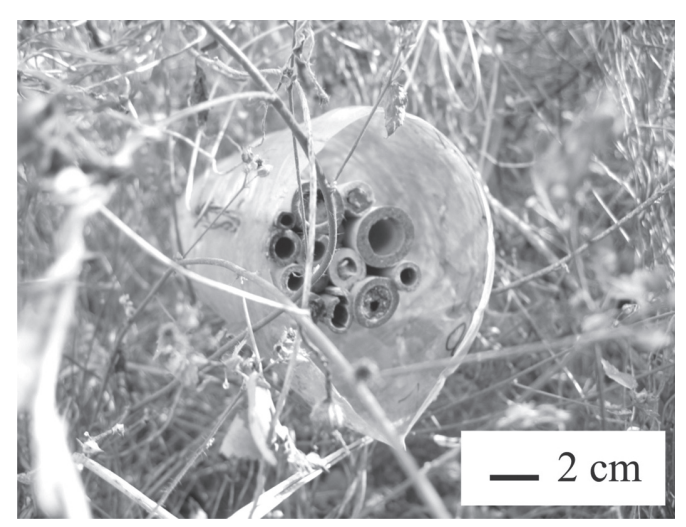

Fig. 2. Trap placed in the field. Trap-nests (internodes of cane) can be seen inside it. Photo credit: A. Altamirano.

laboratory, each individual cane was placed in bags of voile, properly identified and maintained at ambient temperature until emergence of adults (founders or parasites) had ceased. After that, canes were sectioned longitudinally to study the architecture of the nest and cell contents. Given that our aim was to compare species' nest biology, only those nests from which adults were recovered were used to gather data, and thus our results are restricted to the diapause generation.

The identification of insects and their prey, as well as the measurements, were conducted during the first six months of 2007. Species were determined by one of the authors (MLM) through the use of the North American identification key of Trypoxylon species (Coville 1982) and by comparison with the reference collection of the Instituto Miguel Lillo (Tucumán, Argentina). Voucher specimens were deposited in the collection of Centro de Investigaciones Entomológicas, Facultad de Ciencias Exactas, Físicas y Naturales (Universidad Nacional de Córdoba, Argentina).

The principal data gathered were diameter of cane entrance, total nest length, number of brood cells and contents, occurrence of preliminary plug, vestibular (VC) and intercalary cells, and pre-closing plug space (PCPS: an empty space of varying length occurring between the entrance hole and the closing plug). Brood cells were numbered from the interior to the exterior (chronologically the innermost cell was the one constructed first) (Fig. 3). The length of the VC, PCPS and brood cells, maximum thickness of mud partitions and closing plug thickness were recorded. The measurements were taken with digital callipers. The differences in nest architecture (length of nests, number of brood cells, VC, PCPS and brood cell lengths, cell partition thickness, and closing plug thickness) among species, as well as the differences among structures, were compared using ANOVA. Some variables were $\log$ transformed to normalize when necessary, 


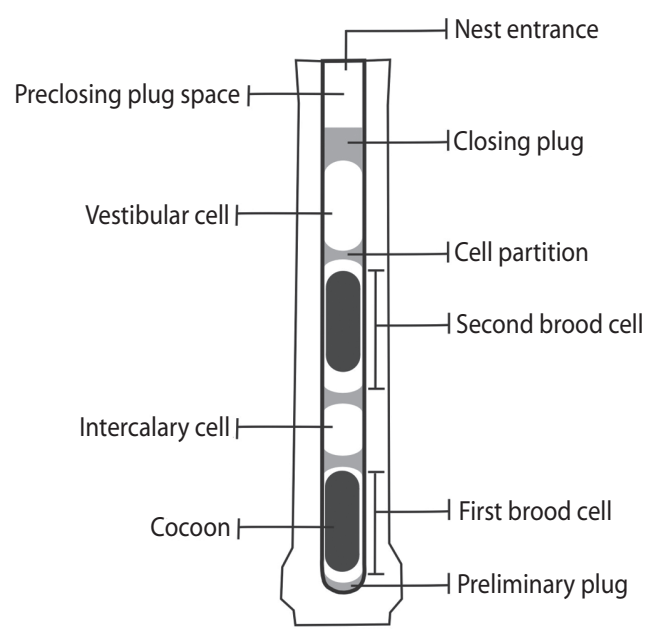

Fig. 3. Cross-section of a trap-nest showing its structures.

and the Kruskall-Wallis non-parametric test was used when assumptions for the ANOVA were not satisfied. The lengths of the closing plugs and the mud partitions were compared using the t-Test. To analyze the relationship between nest structure length and total cane length and nest diameter, linear regressions were performed. The chi-square test was used to compare the number of brood cells in nests with and without VC, and Pearson's correlation to analyze the relationship between brood cell length and cell partition thickness with their order of construction.

As an estimation of body size, fore-tibia lengths of 10 adult wasps of each species were measured using a micrometric eye-piece attached to a microscope at 50X magnification. The relation between fore-tibia length and nest entrance diameter was analyzed using linear regressions. Male vs. female tibia lengths were compared using ANOVA.

The sex ratio was calculated as the number of males over the number of adults (males plus females) reared. The chi-square test was used to test sex ratio deviation from 0.5 , and to compare the sex ratio obtained for each species. The relationship between sex ratios obtained by nest and measurements of the nest (diameter and length) were evaluated by linear regression, after log transformation of the variables. ANOVA was employed to compare the diameter of the nests from which only males emerged and those from which only females emerged.

To analyze the relationship between the nest orientation (S, N, E, W, SE, SW, NW and $\mathrm{NE})$ and the presence or absence of $\mathrm{VC}$ and PCPS, the chi-square test was employed.

Mortality due to unknown causes was calculated for the egg stage (the possible absence of oviposition was included here), as well as for larval and pupal stages. Mortality due to natural enemies was calculated for each species as the percentage of brood cells damaged by parasitoids or kleptoparasites. Chi-square tests were employed to analyze the influence of the presence or absence of VC and PCPS on the mortality rates (parasitism, kleptoparasitism and other unknown causes).

Spiders (prey) obtained from cells in which no wasp larva had developed were preserved in alcohol $(70 \%)$ and identified to the family level with the help of a specialist (see acknowledgements).

\section{RESULTS}

Nest architecture: A total of 91 nests of four species of Trypoxylon were collected and adults were obtained from $58.2 \%$ of these, which were nests in which the wasps spent the winter as immature and emerged the following spring. Sixteen percent of all nests presented a preliminary plug, $48 \%$ a VC and $60 \%$ a PCPS, whereas intercalary cells occurred in just two nests of T. aff. nitidum aztecum (Fig. 3). The occurrence of these structures varied among species (Table 1).

$\mathrm{VC}$ length ranged from $30.7 \mathrm{~mm}$ to $0.82 \mathrm{~mm}$, with the longest found in nests of T. lactitarse and the shortest in the nests of T. aff. nitidum aztecum but average length was similar in all species $\left(\mathrm{F}_{\mathrm{VC}}=2.85, \mathrm{p}=0.06\right.$, d.f.=3). Nests of the species showed no significant differences in PCPS length (ranging from $39 \mathrm{~mm}$ in a $T$. lactitarse nest to $6.7 \mathrm{~mm}$ 
TABLE 1

Occurrence and length of structures of Trypoxylon nests and fore-tibia length of wasps collected in the Chaco Serrano Woodland in Córdoba, Argentina

\begin{tabular}{|c|c|c|c|c|}
\hline & \multicolumn{4}{|c|}{ Species (numbers of nests) } \\
\hline & $\begin{array}{l}\text { T. } \mathrm{sp}_{1} \text { aff. tenoctitlan } \\
\qquad(\mathrm{n}=10)\end{array}$ & $\begin{array}{l}\text { T. lactitarse } \\
(\mathrm{n}=17)\end{array}$ & $\begin{array}{c}T . \mathrm{sp}_{2} \text { aff. tenoctitlan } \\
(\mathrm{n}=14)\end{array}$ & $\begin{array}{l}\text { T. aff. nitidum aztecum } \\
\qquad(\mathrm{n}=12)\end{array}$ \\
\hline Bore diameter & $6.5 \pm 0.4^{\mathrm{B}}$ & $7.8 \pm 0.3^{\mathrm{C}}$ & $7.6+0.4^{\mathrm{BC}}$ & $5.3 \pm 0.3^{\mathrm{A}}$ \\
\hline Total nest length & $129 \pm 10.3^{\mathrm{A}}$ & $120 \pm 9.3^{\mathrm{A}}$ & $121 \pm 7.1^{\mathrm{A}}$ & $103 \pm 9.7^{\mathrm{A}}$ \\
\hline Plug thickness & $2.9 \pm 0.5^{\mathrm{A}}$ & $5.1 \pm 0.6^{\mathrm{B}}$ & $5.7 \pm 0.5^{\mathrm{B}}$ & $3.4 \pm 0.5^{\mathrm{A}}$ \\
\hline $\begin{array}{l}\text { Pre closing plug space } \\
\text { (occurrence) }\end{array}$ & $50 \%$ & $76 \%$ & $63 \%$ & $42 \%$ \\
\hline $\begin{array}{l}\text { Pre closing plug space length } \\
\text { (n of PCPS) }\end{array}$ & $\begin{array}{l}38.3 \pm 3.0 \\
(5)\end{array}$ & $\begin{array}{l}39.2 \pm 12.1 \\
\quad(13)\end{array}$ & $\begin{array}{l}25.7 \pm 6.7 \\
\quad(10)\end{array}$ & $35.2 \pm 10.1$ \\
\hline $\begin{array}{l}\text { Brood cells per nest } \\
\text { (n of brood cells) }\end{array}$ & $\begin{array}{l}6.0+0.9^{\mathrm{A}} \\
(60)\end{array}$ & $\begin{array}{l}3.4+0.6^{\mathrm{A}} \\
(58)\end{array}$ & $\begin{array}{l}4.0+0.6^{\mathrm{A}} \\
(60)\end{array}$ & $\begin{array}{l}4.3+0.5^{\mathrm{A}} \\
\quad(58)\end{array}$ \\
\hline $\begin{array}{l}\text { Preliminary plug } \\
\text { (occurrence) }\end{array}$ & $0 \%$ & $18 \%$ & $29 \%$ & $8 \%$ \\
\hline $\begin{array}{l}\text { Vestibular cell } \\
\text { (occurrence) }\end{array}$ & $60 \%$ & $53 \%$ & $33 \%$ & $33 \%$ \\
\hline $\begin{array}{l}\text { Vestibular cell length } \\
\text { (n of VC) }\end{array}$ & $\begin{array}{c}6.3 \pm 1.0^{\mathrm{A}} \\
(6)\end{array}$ & $\begin{array}{l}30.7 \pm 8.6^{\mathrm{B}} \\
\quad(9)\end{array}$ & $\begin{array}{l}16.2 \pm 2.7^{\mathrm{AB}} \\
(5)\end{array}$ & $\begin{array}{c}8.8 \pm 0.8^{\mathrm{AB}} \\
(4)\end{array}$ \\
\hline $\begin{array}{l}\text { Brood cell length } \\
\text { ( } \mathrm{n} \text { of brood cells) }\end{array}$ & $\begin{array}{c}11.7 \pm 0.3^{\mathrm{A}} \\
(60)\end{array}$ & $\frac{16.5 \pm 0.5^{\mathrm{C}}}{(58)}$ & $\begin{array}{c}17.1 \pm 0.5^{\mathrm{C}} \\
(60)\end{array}$ & $\frac{13.3 \pm 0.5^{\mathrm{B}}}{(58)}$ \\
\hline $\begin{array}{l}\text { Cell partition thickness } \\
\text { (n of cell partitions) }\end{array}$ & $\begin{array}{l}1.9 \pm 0.1^{\mathrm{A}} \\
(61)\end{array}$ & $\frac{2.7 \pm 0.2^{\mathrm{B}}}{(52)}$ & $\begin{array}{l}3.2 \pm 0.1^{\mathrm{C}} \\
(49)\end{array}$ & $\frac{2.7 \pm 0.2^{\mathrm{B}}}{(51)}$ \\
\hline $\begin{array}{l}\text { Fore tibia length } \\
(n=10 \text { adults })\end{array}$ & $2.0 \pm 0.1^{\mathrm{A}}$ & $2.7 \pm 0.1^{\mathrm{B}}$ & $2.8 \pm 0.1^{\mathrm{B}}$ & $2.0 \pm 0.04^{\mathrm{A}}$ \\
\hline $\begin{array}{l}\text { Male tibia length } \\
\text { (n) }\end{array}$ & $\frac{1.8 \pm 0.1^{\mathrm{A}}}{(3)}$ & $\frac{2.6 \pm 0.1^{\mathrm{B}}}{(7)}$ & $2.5 \pm 0.1^{\mathrm{B}}$ & $\frac{1.9 \pm 0.1^{\mathrm{A}}}{(5)}$ \\
\hline $\begin{array}{l}\text { Female tibia length } \\
\text { (n) }\end{array}$ & $\begin{array}{c}2.1 \pm 0.03^{\mathrm{A}} \\
(7)\end{array}$ & $2.9 \pm 0.1^{\mathrm{B}}$ & $\begin{array}{c}2.9 \pm 0.1^{\mathrm{B}} \\
(7)\end{array}$ & $\frac{2.1 \pm 0.1^{\mathrm{A}}}{(5)}$ \\
\hline
\end{tabular}

Measures are given in millimetres $(\mathrm{mm})$. Different letters indicate significant differences by the Duncan test, Alfa=0 05 .

in a $T . \mathrm{sp}_{2}$ aff. tenoctitlan nest $)\left(\mathrm{F}_{\mathrm{PCPS}}=1.37\right.$, $\mathrm{p}=0.28$, d.f. $=3$, Table 1). Neither VC length nor PCPS length were related to total cane length (VC length $\mathrm{R}^{2}$. sp1 aff. tenoctitlan $=0.0001$, $\mathrm{p}=0.9777, \mathrm{R}^{2}{ }_{\text {. sp2 aff. tenoctitlan }}=0.225, \mathrm{p}=0.0739$, $\mathrm{R}^{2}{ }_{T \text {. lactitarse }}=0.0067, \mathrm{p}=0.7548, \mathrm{R}^{2}$ T. aff. nitidum aztecum $=0.0447, \mathrm{p}=0.5090)\left(\mathrm{PCPS}\right.$ length $\mathrm{R}^{2}{ }_{T}$. sp1 aff. tenoctitlan $=0.19, \mathrm{p}=0.2046, \mathrm{R}^{2}$. sp2 aff. tenoctit${ }_{\text {lan }}=0.03, \mathrm{p}=0.5252, \mathrm{R}^{2}$ T. lactitarse $=0.06, \mathrm{p}=0.3605$, $\mathrm{R}^{2}$ T. aff. nitidum aztecum $\left.=0.0024, \mathrm{p}=0.8794\right)$; nor were VC and PCPS lengths related (Pearson's correlation, $\mathrm{r}_{T \text {. sp1 aff. tenoctitlan }}=-0.39, \mathrm{p}=0.27, \mathrm{r}_{T}$. sp2 aff. tenoctitlan $=0.12, \mathrm{p}=0.67, \mathrm{r}_{\text {T. lactitarse }}=-0.16$, $\left.\mathrm{p}=0.54, \mathrm{r}_{\text {T. aff. nitidum aztecum }}=0.05, \mathrm{p}=0.88\right)$.
Nest orientation was not related to the presence of VC or PCPS for any species $\left(T . \mathrm{sp}_{1}\right.$ aff. tenoctitlan: $\chi_{\mathrm{VC}}^{2}=0.28, \mathrm{p}=0.8703$, d.f. $=2$, $\chi_{\text {PCPS }}^{2}=0.67, \mathrm{p}=0.7165$, d.f. $=2, \mathrm{n}=10$ nests, $T$. $\mathrm{sp}_{2}$ aff.tenoctitlan: $\chi_{\mathrm{vC}}^{2}=0.92, \mathrm{p}=0.8203$, d.f. $=3$, $\chi_{\text {PCPS }}^{2}=1.89, \mathrm{p}=0.5965$, d.f. $=3, \mathrm{n}=15$ nests, $T$. aff. nitidum aztecum: $\chi^{2}{ }_{\mathrm{vC}}=3, \mathrm{p}=0.5578$, d.f. $=4$, $\chi_{\text {PCPS }}^{2}=6.51, \mathrm{p}=0.1639$, d.f. $=4, \mathrm{n}=12$ nests; and T. lactitarse: $\chi^{2}{ }_{\mathrm{VC}}=12.32, \mathrm{p}=0.0553$, d.f. $=6$, $\chi_{\text {PCPS }}^{2}=9.78, \mathrm{p}=0.1345$, d.f. $=6, \mathrm{n}=17$ nests).

The canes used by T. aff. nitidum aztecum had the lowest diameter, while $T$. lactitarse seemed to prefer the widest cane diameters $(\mathrm{F}=10.86, \mathrm{p}<0.0001$, d.f. $=3)$. Differences in 
cane diameters used by other species were not significant. The average length of nests constructed by each species varied between 10.3 and $12.9 \mathrm{~cm}$ with no significant differences among them $(\mathrm{F}=1.25, \mathrm{p}=0.30$, d.f. $=3)$.

The average number of cells per nest ranged from 3.4 to 6.0 with no significant differences among species $(\mathrm{F}=2.63, \mathrm{p}=0.06$, d.f.=3).

Brood cell lengths, cell partition thickness and closing plug thickness differed among species (Kruskall Wallis test ${ }_{\text {cells }}=89.1, \mathrm{p}<0.0001$, $\mathrm{F}_{\text {cell partitions }}=25.1, \mathrm{p}<0.0001$, d.f. $=3.0, \mathrm{~F}_{\text {closing }}$ plugs $=5.76, \mathrm{p}=0.0018$, d.f. $=3$ ). Trypoxylon $\mathrm{sp}_{2}$ aff. tenoctitlan built the longest brood cells and the thickest partitions and closing plugs. The shortest brood cells and the thinnest partitions and plugs were built by $T$. $\mathrm{sp}_{1}$ aff. tenoctitlan (Table 1).

The closing plugs were thicker than the mud partitions for $T$. $\mathrm{sp}_{1}$ aff. tenoctitlan, $T$. $\mathrm{sp}_{2}$ aff. tenoctitlan and $T$. lactitarse but not for T. aff. nitidum aztecum (t-test ${ }_{T \text {. sp1 aff. tenoctit- }}$ lan $=-2.82, \mathrm{p}=0.0168, \mathrm{t}$-test $T_{\text {. } \mathrm{sp} 2 \text { aff. tenoctitlan }}=-4.44$, $\mathrm{p}=0.0004$, t-test $_{T}$. lactitarse $=-2.87, \mathrm{p}=0.0082$, $\mathrm{t}^{- \text {test }_{\text {. aff. nitidum aztecum }}}=-1.37, \mathrm{p}=0.1891$ ).

The brood cell lengths of the nests were inversely correlated with their order of construction for the nests of T. aff. nitidum aztecum, T. $\mathrm{sp}_{1}$ aff. tenoctitlan and T. $\mathrm{sp}_{2}$ aff. tenoctitlan but not of T. lactitarse. $\left(\mathrm{r}_{T \text {. aff. nitidum }}\right.$ aztecum $=-0.31, \mathrm{p}=0.02, \mathrm{r}_{T \text {. sp1 aff. tenoctitlan }}=-0.33$, $\mathrm{p}=0.01, \mathrm{r}_{T}$. sp2 aff. tenoctitlan $=-0.541, \mathrm{p}<0.0001$, $\mathrm{r}_{\text {T. lactitarse }}=-0.13, \mathrm{p}=0.32$ ); the first brood cells (built by the wasp at the bottom of the nest) were the longest ones and the last cells the shortest. Cell partition thickness was positively correlated with the order of construction for $T$. aff. nitidum aztecum and $T . \mathrm{sp}_{2}$ aff. tenoctitlan but not for $T$. $\mathrm{sp}_{1}$ aff. tenoctitlan and T. lactitarse $\left(\mathrm{r}_{T \text {. aff. nitidum aztecum }}=0.26, \mathrm{p}=0.05, \mathrm{r}_{T \text {. sp2 aff. }}\right.$. tenoctitlan $=0.43, \mathrm{p}<0.0001, \mathrm{r}_{T . \mathrm{sp} 1 \text { aff. tenoctitlan }}=0.21$, $\left.\mathrm{p}=0.09, \mathrm{r}_{\text {T. lactitarse }}=0.06, \mathrm{p}=0.66\right)$.

In the nests of T.aff. nitidum aztecum and $T$. $\mathrm{sp}_{1}$ aff. tenoctitlan, $\mathrm{VC}$ were shorter than brood cells and than PCPS (Kruskall Wallis test ${ }_{T \text {. aff. }}$ nitidum aztecum $=8.29, \mathrm{p}=0.0159, \mathrm{H}_{T}$. sp1 aff. tenoctit-
lan $=8.05, \mathrm{p}=0.0178)$. In T. $\mathrm{sp}_{2}$ aff. tenoctitlan and $T$. lactitarse nests, the length of VC, PCPS and brood cells was similar (Kruskall Wallis test $_{\text {. } . \mathrm{sp} 2 \text { aff. tenoctitlan }}=0.24, \mathrm{p}=0.887, \mathrm{H}_{T \text {. lacti- }}$ tarse $=3.62, \mathrm{p}=0.1636$ ) (Table 1$)$.

The number of brood cells per cane was positively correlated with the length of the cane in nests of T. lactitarse and T. $\mathrm{sp}_{2}$ aff. tenoctitlan $\left(\mathrm{R}^{2}\right.$ T. lactitarse $=0.26, \mathrm{p}=0.0374, \mathrm{n}=17, \mathrm{R}^{2}{ }_{\text {. } \mathrm{sp} 2}$ aff. tenoctitlan $=0.31, \mathrm{p}=0.0302, \mathrm{n}=15)$. There was no relationship between the number of brood cells and nest diameter for any of the species studied. In the nests of $T$. $\mathrm{sp}_{1}$ aff. tenoctitlan the number of brood cells per nest with vestibular cell $(7 \pm 1.03, \mathrm{n}=6$ nests) was greater than that of nests without vestibular cell $(4.5 \pm 1.5, \mathrm{n}=4$ nests) $\left(\chi^{2}=9.6\right.$, d.f. $\left.=1, p=0.0019\right)$.

The diameter of the nest entrance explained $49 \%$ of the variation found in fore-tibia length for T. aff. nitidum aztecum and $45 \%$ for $T$. $\mathrm{sp}_{2}$ aff. tenoctitlan $\left(\mathrm{R}^{2}=0.49, \mathrm{p}=0.02, \mathrm{n}=10\right.$ and $\mathrm{R}^{2}=0.45, \mathrm{p}=0.03, \mathrm{n}=10$ respectively). No such relationships were found for other species $\left(\mathrm{R}^{2}\right.$. sp1 aff. tenoctitlan $=0.07, \mathrm{p}=0.4525, \mathrm{n}=10$ and $\mathrm{R}^{2}{ }_{T}$. lactitarse $=0.22, \mathrm{p}=0.1668, \mathrm{n}=10$ ).

Male fore-tibia lengths were smaller than females $\left(\mathrm{F}_{T \text {. sp2 aff. tenoctitlan }}=10.27, \mathrm{p}=0.01, \mathrm{n}=10\right.$, $\mathrm{F}_{\text {T. lactitarse }}=5.88, \mathrm{p}=0.04, \mathrm{n}=10, \mathrm{~F}_{T \text {. sp1 aff. tenoctit- }}$ lan $=12.03, \mathrm{p}=0.008, \mathrm{n}=10, \mathrm{~F}_{\text {T. aff. nitidum aztecum }}=$ 2.77, $\mathrm{p}=0.1349, \mathrm{n}=10$, Table 1 ).

Sex ratios: The sex ratios obtained were similar in the species studied $\left(T . \mathrm{sp}_{1}\right.$ aff. tenoctitlan $=0.43, T$. lactitarse $=0.46, T . \mathrm{sp}_{2}$ aff. tenoctitlan $=0.44$ and $T$. aff. nitidum aztecum $=$ $0.69, \chi_{\text {among species }}^{2}=3.24$, d.f. $=3, \mathrm{p}=0.36$ ), and did not depart significantly from a sex ratio of $0.5\left(\chi^{2}=1.80 \mathrm{E}-04\right.$, d.f. $\left.=1, \mathrm{p}=0.99\right)$.

The diameter of the nest entrance of $T . \mathrm{sp}_{1}$ aff. tenoctitlan was smaller in those nests from which only males emerged $(4.83 \pm 0.12 \mathrm{~mm})$ than in those from which only females emerged $(7.00 \pm 0.44 \mathrm{~mm})(\mathrm{F}=69.26, \mathrm{p}=0.0011, \mathrm{n}=6)$. Male and female nest diameters were similar for $T$. $\mathrm{sp}_{2}$ aff. tenoctitlan, $T$. aff. nitidum aztecum and T. lactitarse $\left(\mathrm{F}_{T . \mathrm{sp} 2 \text { aff. tenoctitlan }}=1.6, \mathrm{p}=0.2376\right.$, $\mathrm{n}=11, \mathrm{~F}_{\text {T. aff. nitidum aztecum }}=0.67, \mathrm{p}=0.4494, \mathrm{n}=7$, $\left.\mathrm{F}_{\text {T. lactitarse }}=0.01, \mathrm{p}=0.9327, \mathrm{n}=14\right)$. The proportion of males per nest of $T$. $\mathrm{sp}_{1}$ aff. tenoctitlan 
was inversely related to the diameter of the nest entrance $\left(\mathrm{R}^{2}=0.92, \mathrm{p}=0.0007\right)$. Such relationships were not found for the other species $\left(\mathrm{R}^{2}{ }_{T \text {. sp2 aff. tenoctitlan }}=0.19, \mathrm{p}=0.1374, \mathrm{n}=13, \mathrm{R}^{2}{ }_{T}\right.$. lactitarse $=0.0004, \mathrm{p}=0.6908, \mathrm{n}=12, \mathrm{R}^{2}{ }_{\text {T. aff. nitidum }}$ aztecum $=0.15, \mathrm{p}=0.3017, \mathrm{n}=9$ ).

Mortality and natural enemies: The most important mortality factor was the death of immature forms, which was observed in 37 cells $(16 \%)$, occurring in pupae $(2 \%)$, larvae $(3 \%)$ or egg stages $(11 \%)$. Natural enemies accounted for $9 \%$ of the pre-adult mortality, and $6 \%$ of this mortality was due to two genera of kleptoparasites in the family Chrysididae (Hymenoptera), Neochrysis sp. Linsenmaier on T. lactitarse and $T . \mathrm{sp}_{2}$ aff. tenoctitlan, and Pleurochrysis sp. Bohart on T. $\mathrm{sp}_{1}$ aff. Tenoctitlan. The parasitoid Melittobia sp. Westwood (Eulophidae) caused 3\% of the mortality due to natural enemies on T. lactitarse, $T$. $\mathrm{sp}_{2}$ aff. tenoctitlan and T. aff. nitidum aztecum (Table 2).

The presence of VC had no significant influence on mortality due to parasitoids or kleptoparasitoids in the nests of $T$. aff. nitidum aztecum, T. $\mathrm{sp}_{2}$ aff. tenoctitlan or $T . \mathrm{sp}_{1}$ aff. tenoctitlan $\left(\chi_{T \text {. aff. nitidum aztecum }}^{2}=0\right.$, d.f. $=0, \mathrm{p}=\mathrm{sd}$, $\chi_{T \text {. sp2 aff. tenoctitlan }}^{2}=0.14$, d.f. $=1, \mathrm{p}=0.7094, \chi_{T}^{2}$. sp1 aff. tenoctitlan $=0$, d.f. $=0, \mathrm{p}=\mathrm{sd}$ ). Mortality due to parasitoids in nests of $T$. lactitarse without a $\mathrm{VC}$ was higher than expected by chance and mortality in nests with VC was lower than expected. Exactly the opposite pattern was observed with mortality due to kleptoparasites, which was higher in nests with VC and lower in nests without VC $\left(\chi^{2}=5.094\right.$, d.f. $=1$, $\mathrm{p}=0.0241$ ).

The nests of three out of four species studied (T. lactitarse, $T$. $\mathrm{sp}_{2}$ aff. tenoctitlan and $T$. $\mathrm{sp}_{1}$ aff. tenoctitlan) suffered mortality levels directly related to the number of brood cells in the nest $\left(\mathrm{R}^{2}\right.$. lactitarse $=0.26, \mathrm{p}=0.04, \mathrm{n}=17$, $\mathrm{R}^{2}{ }_{\text {. sp2 aff. tenoctitlan }}=0.25, \mathrm{p}=0.05, \mathrm{n}=15, \mathrm{R}^{2}{ }_{T \text {. } \mathrm{sp} 1}$ aff. tenoctitlan $=0.38, \mathrm{p}=0.05, \mathrm{n}=10$ ). Mortality due to kleptoparasites was higher in the first constructed cells in nests of $T$. lactitarse $\left(\mathrm{R}^{2}=0.85\right.$, $\mathrm{p}=0.0002, \mathrm{n}=10)$ and $T . \mathrm{sp}_{2}$ aff. tenoctitlan $\left(\mathrm{R}^{2}=0.37, \mathrm{p}=0.06, \mathrm{n}=10\right)$.

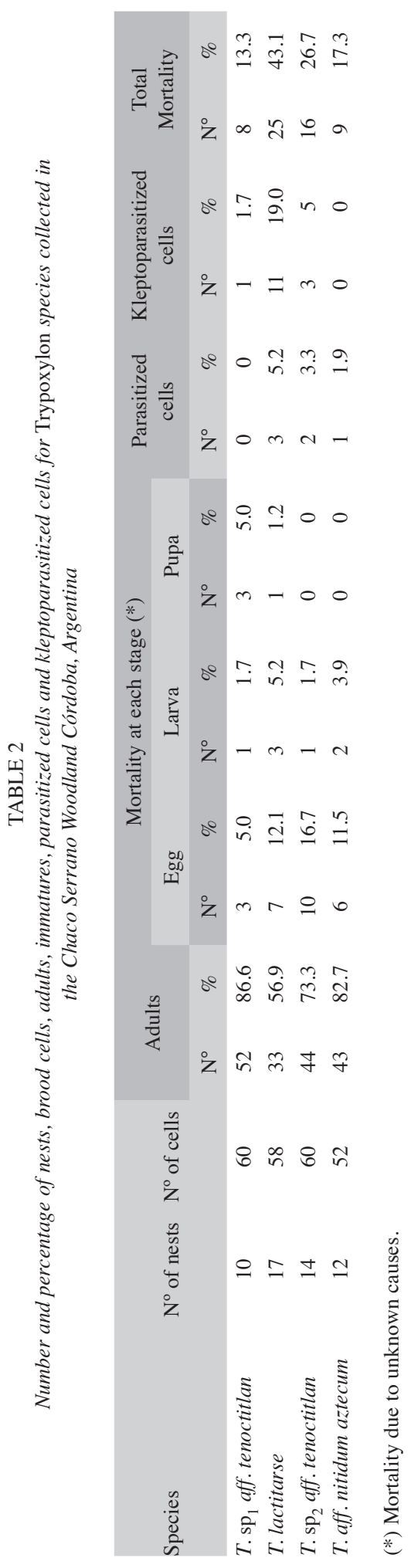


Collected prey: A total of 500 spiders, used by female wasps to supply the cells, were recovered from 77 brood cells of 39 nests. The spiders belonged to seven families: Araneidae (85\%), Thomisidae (10\%), Theridiidae (2\%), Heteropodidae (1\%), Salticidae (1\%), Anyphaenidae $(0.6 \%)$ and Lycosidae $(0.2 \%)$.

Spiders hunted by $T$. lactitarse ( $\mathrm{n}=8$ nests) and $T . \mathrm{sp}_{2}$ aff. tenoctitlan ( $\mathrm{n}=7$ nests) belong mostly to the family Araneidae, while T. aff. nitidum aztecum ( $\mathrm{n}=5$ nests) and $T$. $\mathrm{sp}_{1}$ aff. tenoctitlan ( $\mathrm{n}=3$ nests) had a more diverse range of prey including Araneidae, Heteropodidae, Salticidae, Theridiidae and Anyphaenidae found in nests of T. aff. nitidum aztecum; Araneidae, Thomisidae, Salticidae and Lycosidae in nests of $T$. $\mathrm{sp}_{1}$ aff. tenoctitlan 16 nests could not be assigned to a Trypoxylon species.

\section{DISCUSSION}

The structure of Trypoxylon nests analyzed in this study was similar among the different species and also to the features of nests constructed by females of the subgenus Trypargilum previously described (Coville 1982). At least one generation of all the species recorded in the Chaco Serrano Woodland passed the winter as immatures, as has been observed for many other species of Trypoxylon (e.g. Coville 1982, Brockmann \& Grafen 1991, Camillo et al. 1993, Peruquetti \& Del Lama 2003, Jenkins \& Matthews 2004, Boesi et al. 2005, Buschini \& Wolff 2006, Buschini et al. 2006, Buschini 2007). The low temperatures in Córdoba during the winter could be a factor favoring diapause in these insects.

Preliminary plug, vestibular cell and empty intercalary cells were frequent but not constant structures of the nests studied. Although Krombein (1967) mentioned that a preliminary plug is a constant feature of subgenus Trypargilum nests, we found that more than $80 \%$ of the nests lacked such structure. This disparity may be attributed to differences in the trap nests used in both studies, which were holes made in wood with a twist drill in the first case and canes in the second. Probably the rougher, more pointed inner end of a drilled boring was perceived by the female wasps as not smooth and so needing to be closed off by a preliminary plug, whereas the natural cavities in canes are quite smooth so that a preliminary plug would be less frequently necessary.

The role of the vestibular cell has been widely discussed. Krombein (1967) proposed that it discourages penetration to the provisioned cells by predators, parasites and nest destroyers; whereas Seidelmann (1999) suggested that it serves as a buffer space to reduce the progeny's mortality from adverse environmental conditions. Asís et al. (2007) proposed that a VC is a completion structure made to fill the remainder space of the chosen burrow, after the nest was finished. In other words, it would be present when the chosen cavity is longer than required to construct the optimum number of cells for the species. According to this hypothesis, a vestibular cell would avoid the possibility of other individuals constructing a nest in the remaining space of the burrow ("supersedure"), increasing the mortality of individuals reared in the innermost cells at the moment of emergence.

Our results did not support any of these hypotheses. We did not find evidence, for any of the species studied, that there is a relationship between natural enemy incidence and VC occurrence, which agrees with several studies analyzing this hypothesis (García \& Adis 1995, Weaving 1995, Seidelmann 1999). Also, we did not find a relationship between VC occurrence and trap nest orientation in the field, so we cannot support the hypothesis that this structure is constructed as a buffer space against harsh environmental conditions at the nest (Seidelmann 1999) (sun exposure, wind or precipitation incidence). Lastly, our results showed that vestibular cell length was not long enough to construct an additional brood cell, which supports the hypothesis of $\mathrm{VC}$ being a completion structure (Asís et al. 2007). However, our data also constitute evidence against this hypothesis, since $30 \%$ of the nests presented, besides a vestibular cell, a pre-closing plug space. This empty space might be used by females of 
other species to breed and thus, in such cases, supersedure would not have been avoided. The availability of these empty spaces in a high proportion of nests $(60 \%)$ suggests that females do not compete for nesting cavities in this study area. It should be remarked that the pre-closing plug space (PCPS) is a structure not previously considered in studies on Trypoxylon nesting, even when the space is observed in nest illustrations (Buschini et al. 2006).

As regards empty intercalary cells, it has been suggested that wasp females may construct these to avoid damage in the newly constructed cells, isolating them from those parasitized or fungus-contaminated (Krombein 1967). It was reported that empty cells are rather common in T. lactitarse nests in Southern Brazil (Camillo et al. 1993, Assis \& Camillo 1997). We observed intercalary cells only in two nests of T. aff. nitidum aztecum and these were not related with symptoms of parasitism or contamination.

Cavities preferred by $T$. lactitarse in this study were of similar diameter to those mentioned in the literature (Camillo et al. 1993, Assis \& Camillo 1997, Buschini et al. 2006, Buschini \& Wolff 2006). It has been demonstrated that preference for a particular diameter of pre-existing tubular cavities may change due to inter- and intra-specific competition for available spaces (Krombein 1967, Coville 1982). At least for two of the species studied, trap-nest diameter was related to the fore-tibia size of emerged wasps, as previously described for other Crabronidae species (Krombein 1961, Fricke 1991, García \& Adis 1995, Assis \& Camillo 1997).

According to Coville (1982), smaller diameter borings produce mostly males in some species, as observed here for $T . \mathrm{sp}_{1}$ aff. tenoctitlan. If female Hymenoptera fertilize the eggs they lay, then they have daughters. If the eggs are not fertilized, then sons are produced (Brockmann \& Grafen 1991). Thus, a possible explanation for a greater production of males in smaller diameter nests could be that the lack of space in those nests makes copulation dif- ficult, so that females lay an unfertilized egg (Buschini 2007).

The number of brood cells depends upon nest dimensions, is related to the body size of the wasp, and it is possible that each species has an inherent maximum number (Coville 1982). A relationship between number of brood cells and cavity diameter has been found in nests of several species: T. lactitarse (Krombein 1967, Coville 1981, Assis \& Camillo 1997), T. tenoctitlan (Coville \& Coville 1980) and T. rogenhoferi (Assis \& Camillo 1997); but this relationship was not found for any species studied here. The average number of brood cells observed for T. lactitarse by Camillo and Brescovit (1999a) (4 brood cells in nests with diameter of $10 \mathrm{~mm}$ ) was also the most frequent value obtained here. In our data we also observed a relationship between nest length and number of brood cells.

Sex ratios: As previously observed for $T$. lactitarse (Buschini et al. 2006), T. anttenatum and $T$. beaumonti (Tormos et al. 2005), the sex ratio of all species studied here did not differ significantly from 0.5 . Given that males are smaller than females, this fact conflicts with the theory of parental investment (Fisher 1999), which sustains that large randomly breeding population selection will result in equal investment in sons and daughters (Tormos et al. 2005). However, caution should be taken in drawing conclusions about sex ratios when little data is available (Oku \& Nishida 2001).

Mortality and natural enemies: Sources of mortality observed in this study were similar to those mentioned by other authors: development failures (unknown causes), parasitoids and kleptoparasites. Development failures have been documented as important causes of mortality: Camillo et al. (1993) observed a mortality rate of $7.7 \%$ for T. lactitarse in south-eastern Brazil, while higher values have been reported for the same species in southern Brazil, fluctuating from $23 \%$ to $47 \%$ and depending on the length of the nest (Buschini et al. 2006). 
Trypoxylon lactitarse nests in southern Brazil have been attacked by Chrysididae, Eulophidae, Ichneumonidae (Hymenoptera), Sarcophagidae and Phoridae (Diptera) (Buschini \& Wolff 2006). We found a lower diversity of natural enemies, including only the first two above-mentioned hymenopteran families. Mortality rates due to natural enemies ranging between $24 \%$ and $41 \%$ have been reported for T. lactitarse (Camillo et al. 1993, Buschini \& Wolff 2006) and we too found mortality rates in the lower limit of this range. Other Trypoxylon species here showed even lower values of parasitoidism, similar to those observed for two species in different localities in Spain $(2.4 \%)$ (Tormos et al. 2005).

Collected prey: Trypoxylon $\mathrm{sp}_{2}$ aff. tenoctitlan and $T$. lactitarse showed a strong preference for Araneidae species to supply their nests. Similar data were obtained for the latter species in Southern Brazil (Camillo et al. 1993, Camillo \& Brescovit 1999a, Gonzaga \& Vasconcellos-Neto 2005, Buschini et al. 2008) and also in Costa Rica (Coville 1979, 1981, Coville et al. 2000). The preference of some Trypoxylon species for Araneidae has been previously mentioned (Rehnberg 1987, Camillo \& Brescovit 1999a). Trypoxylon aff. nitidum aztecum was the more generalist species according to our data, including five of the seven spider families recorded in the nests.

We believe that further work is required on the Trypoxylon species in the Southern Neotropics region, centering on their life history, mainly phenology and seasonality, female investment in progeny and sex-allocation patterns.

\section{RESUMEN}

En este trabajo se estudia la biología de la nidificación de cuatro especies de Trypoxylon (Trypargilum) recolectadas a partir de 91 nidos-trampa en el Bosque Chaqueño Serrano de Córdoba, Argentina. La arquitectura de los nidos fue similar para las cuatro especies: celdas de cría ubicadas linealmente, una detrás de la otra separadas por tabiques de barro, como es habitual en otras especies del subgénero Trypargilum. El 48\% de los nidos presentó celda vestibular, mientras que sólo dos nidos presentaron celdas intercalares. El ancho de los tabiques y el largo de las celdas de cría difirió entre las especies y estuvo relacionado con el tamaño de las avispas que emergieron. Asî mismo, el diámetro del nido-trampa estuvo directamente relacionado con el tamaño corporal promedio de las especies de mayor y menor tamaño. La mortalidad debida a parasitoides (Eulophidae; Melittobia sp.) fue similar para las cuatro especies, mientras que la causada por cleptoparásitos (Chrysididae) fue mayor en T. lactitarse. No fue posible relacionar la presencia de celda vestibular con la mortalidad debida a enemigos naturales para ninguna de las especies. La familia de arañas más frecuentemente utilizada como presa fue Araneidae.

\section{ACKNOWLEDGMENTS}

We thank Iliana Martinez and Ann Zillikens for valuable suggestions that improved previous versions of the manuscript. We also thank Matías Izquierdo for helping in spider identification, Rodolfo Foglia, Carlos Buasso, Julia Astegiano and Mariana Jausoro for field assistance and Lidwina Bertrand and Evangelina Minuzzi-Fahn for laboratory assistance. Special thanks to Joss Heywood for reviewing the manuscript translation. This research was supported by CONICET, FONCYT and Ministerio de Ciencia y Tecnología de la Provincia de Córdoba and by a grant from CONICET (M.L.M.). A.S. is a CONICET research fellow.

\section{REFERENCES}

Asís, J.D., A. Benéitez, J. Tormos, S.F. Gayubo \& M.A. Martín-Tomé. 2007. The significance of the vestibular cell in trap nesting wasps (Hymenoptera: Crabronidae): Does its presence reduce mortality? J. Insect Behav. 20: 289-305.

Assis, J.M.F. \& E. Camillo 1997. Diversidade, sazonalidade e aspectos biológicos de vespas solitarias (Hymenoptera: Sphecidae: Vespidae) em ninhos armadilhas na região de Ituitaba, MG. An. Soc. Entomol. Brasil 26: 335-347.

Boesi, R., C. Polidori, J. Tormos, S. Benacqua, J.D. Asís \& F. Andrietti. 2005. Trap-Nesting Ancistrocerus sikhimensis (Hymenoptera: Eumenidae) in Nepal: nest structure and associates (Hymenoptera: Chrysididae; Acarina: Saproglyphidae). Fla. Entomol. 88: 135-140. 
Bohart, R.M. \& A.S. Menke. 1976. Sphecid wasps of the world, a generic revision. University of California Press, Berkeley, USA.

Brockmann, H.J. \& A. Grafen. 1989. Mate conflict and male behaviour in a solitary wasp, Trypoxylon (Trypargilum) politum (Hymenoptera: Sphecidae). Anim. Behav. 37: 232-255.

Brockmann, H.J. \& A. Grafen. 1991. Sex ratios and life-history patterns of a solitary wasp, Trypoxylon (Trypargilum) politum (Hymenoptera: Sphecidae). Behav. Ecol. Sociobiol. 30: 7-27.

Brockmann, H.J. 1992. Male behavior, courtship and nesting in Trypoxylon (Trypargilum) monteverdeae (Hymenoptera: Sphecidae). J. Kans. Entomol. Soc. 65: 66-84.

Buschini, M.L.T. \& L.L. Wolff. 2006. Notes on the biology of Trypoxylon (Trypargilum) opacum Brèthes (Hymenoptera; Crabronidae) in Southern Brazil. Braz. J. Biol. 66: 907-917.

Buschini, M.L.T., F. Niesing \& L.L. Wolff. 2006. Nesting biology of Trypoxylon (Trypargilum) lactitarse Saussure (Hymenoptera, Crabronidae) in trap-nests in Southern Brazil. Braz. J. Biol. 66: 919-929.

Buschini, M.L.T. 2007. Life-hystory and sex allocation in Trypoxylon (syn. Trypargilum) lactitarse (Hymenoptera; Crabronidae). J. Zool. Syst. Evol. Res. 45: 206-213.

Buschini, M.L.T., N.A. Borba \& A.D. Brescovit. 2008. Patterns of prey selection of Trypoxylon (Trypargilum) lactitarse Saussure (Hymenoptera: Crabronidae) in Southern Brazil. Braz. J. Biol. 68: 519-528.

Cabido, M., M.L. Carranza, A. Acosta \& S. Páez. 1991. Contribución al conocimiento fitosociológico del Bosque Chaqueño Serrano en la provincia de Córdoba, Argentina. Phytocoenología 19: 547-566.

Camillo, E., C.A. Garofalo, G. Muchillo \& J.C. Serrano. 1993. Biological observations on Trypoxylon (Trypargilum) lactitarse Saussure in Southeastern Brazil (Hymenoptera: Sphecidae). Rev. Bras. Entomol. 37: 769-27.

Camillo, E., C.A. Garofalo \& J.C. Serrano. 1994. Biological observation of Trypoxylon (Trypargilum) rogenhoferi Kohl (Hymenoptera: Sphecidae). An. Soc. Entomol. Brasil 23: 299-310.

Camillo, E. \& A.D. Brescovit. 1999a. Spiders (Araneae) captured by Trypoxylon (Trypargilum) lactitarse (Hymenoptera: Sphecidae) in Southeastern Brazil. Rev. Biol. Trop. 47: 149-160.
Camillo, E. \& A.D. Brescovit. 1999b. Aspectos biológicos de Trypoxylon (Trypargilum) lactitarse Saussure e Trypoxylon (Trypargilum) rogenhoferi Kohl (Hymenoptera: Sphecidae) em ninhos-armadilhas, com especial referencia a suas presas. An. Soc. Entomol. Bras. 28: 251-262.

Camillo, E. \& A.D. Brescovit. 2000. Spider prey (Araneae) of Trypoxylon (Trypargilum) rogenhoferi (Hymenoptera: Sphecidae) in Southeastern Brazil. Rev. Biol. Trop. 48: 647-656.

Coville, R.E. 1979. Biological observations on Trypoxylon (Trypargilum) arizonense in Arizona (Hymenoptera: Sphecidae). J. Kans. Entomol. Soc. 52: 613-620.

Coville, R.E. \& P.L. Coville. 1980. Nesting biology and male behavior of Trypoxylon (Trypargilum) tenoctitlan in Costa Rica (Hymenoptera: Sphecidae). Ann. Entomol. Soc. Am. 73: 110-119.

Coville, R.E. 1981. Biological observations on three Trypoxylon wasps in the subgenus Trypargilum from Costa Rica: T. nitidiu schultesi, T. saussurei and T. lactitarse (Hymenoptera: sphecidae). Pan-Pacif. Ent. 57: $332-340$.

Coville, R.E. 1982. Wasps of the genus Trypoxylon subgenus Trypargilum in North America (Hymenoptera: Sphecidae). University of California, Publications in Entomology, Berkeley, California, USA.

Coville, R.E., C.E. Griswold \& P.L. Coville. 2000. Observations on the nesting biology and behavior of Trypoxylon (Trypargilum) vagumm (Hymenoptera: Sphecidae) in Costa Rica. Pan-Pacif. Ent. 76: 28-48.

Fisher, R.A. 1999. The genetical theory of natural selection. A Complete Variorum Edition. Oxford University Press, Oxford, England.

Fricke, J.M. 1991. Trap-nest bore diameter preferences among sympatric Passaloecus spp. (Hymenoptera, Sphecidae). Great Lakes Entomol. 24: 123-125.

Garcia, M.V.B. \& J. Adis. 1995. Comportamento de nidificação de Trypoxylon (Trypargilum) rogenhoferi Kohl (Hymenoptera: Sphecidae) em una floresta inundável de várzea na Amazônia Central. Amazoniana 18: 259-288.

Genaro, J.A., C.S. Sánchez \& G. Alayon García. 1989. Notas sobre la conducta de nidificación de Trypoxylon (Trypargilum) subimpressum Smith (Hymenoptera: Sphecidae). Caribb. J. Sci. 25: 228-229.

Genaro, J.A. 1996. Estructura del nido y capullo de Trypoxylon (Trypargilum) subimpressum (Hymenoptera: Sphecidae). Caribb. J. Sci. 32: 243-244. 
Gonzaga, M.O. \& J. Vasconcellos-Neto. 2005. Orb-web spiders (Araneae: Araneomorphae; Orbiculariae) captured by hunting-wasps (Hymenoptera: Sphecidae) in an area of Atlantic Forest in south-eastern Brazil. J. Nat. Hist. 39: 2913-2933.

Hanson, P.E. \& A.S. Menke. 1995. The sphecid wasps (Sphecidae), p. 621-649. In P.E. Hanson \& I.D. Gauld (eds.). The Hymenoptera of Costa Rica, Oxford University Press, New York.

Jenkins, D.A. \& R.W. Matthews. 2004. Cavity-nesting Hymenoptera in disturbed habitats of Georgia and South Carolina: nest architecture and seasonal occurrence. J. Kansas Entomol. Soc. 77: 203-214.

Jiménez, M.L. \& A. Tejas. 1994. Las arañas presa de la avispa lodera Trypoxylon (Trypargilum) tridentatum tridentatum en Baja California Sur, México. Southwest Entomol. 19: 173-180.

Krombein, K.V. 1961. Some symbiotic relations between saprogyphid mites and solitary vespid wasps. J. Washington Acad. Sci. 51: 89-93.

Krombein, K.V. 1967. Trap-nesting wasps and bees: life histories, nests, and associates. Smithsonian, Washington, D.C., USA.

Luti, R., M. Bertrán, M. Galera, N. Muller, M. Berzal, M. Nores, M. Herrera \& J.C. Barrera. 1979. Vegetación, p. 297-268. In Geografía Física de la Provincia de Córdoba. Boldt, Buenos Aires, Argentina.

Menke, A.S. \& F. Fernández. 1996. Claves ilustradas para las subfamilias, tribus y géneros de esfécidos neotropicales (Apoidea: Sphecidae). Rev. Biol. Trop. 44: $1-68$.

Morato, E.F. \& L.A. Campos de O. 1994. Aspectos da biologia de Pisoxylon xanthosoma na amazônia central
(Hymenoptera, Sphecidae, Larrinae, Trypoxylonini). Rev. Bras. Entomol. 38: 585-594.

Oku, S. \& T. Nishida. 2001. Presence of single-sex broods under local mate competition in Trypoxylon malaise (Hymenoptera: Sphecidae): adaptation or maladaptation? Ann. Entomol. Soc. America 94: 550-554.

Peruquetti, R.C. \& M.A. Del Lama. 2003. Notas sobre a socialidade e a biologia de nidificação de Trypoxylon (Trypoxylon) asuncicola Strand, 1910 (Hymenoptera, Sphecidae). Rev. Bras. Entomol. 47: 297-301

Rehnberg, B.G. 1987. Selection of spider prey by Trypoxylon politum (Say) (Hymenoptera: Sphecidae). Can. Net. 119: 189-194.

Seidelmann, K. 1999. The function of the vestibulum in nests of a solitary stem-nesting bee, Osmia rufa (L:). Apidologie 30: 19-29.

Tormos, J., J.D. Asís, S.F. Gayubo, J. Calvo \& M.A. Martín. 2005. Ecology of crabronid wasps found in trap nests from Spain (Hymenoptera: Spheciformes). Fla. Entomol. 88: 278-284.

Tscharntke, T., A. Gathmann \& I. Steffan-Dewenter. 1998. Bioindication using trap-nesting bees and wasps and their natural enemies: community structure and interactions. J. Appl. Ecol. 35: 708-719.

Weaving, A.J.S. 1995. A comparison of nesting success and nesting habits in some Afrotropical aculeate wasps, with particular reference to nest parasites. Ann. Cape Prov. Mus. Nat. Hist. 19: 181-224.

Zak, M.R., M. Cabido \& J.G. Hodgson. 2004. Do subtropical seasonal forests in the Gran Chaco, Argentina, have a future? Biol. Conserv. 120: 589-598. 